\title{
Renal medullary carcinoma
}

INSERM

\section{Source}

INSERM. (1999). Orphanet: an online rare disease and orphan drug data base. Renal medullary carcinoma. ORPHA:319319

Renal medullary carcinoma is a rare, aggressive subtype of renal cell carcinoma characterized by a large, white or tan, firm, infiltrative tumor with microabscess-like foci centered in the renal medulla, typically presenting with hematuria, abdominal/flank pain, weight loss and fever. It is associated with sickle cell trait and disease and metastasis to the bones and lungs is common at time of diagnosis. 